\title{
Baseline Sensitivities for New Postharvest Fungicides Against Penicillium spp. on Citrus and Multiple Resistance Evaluations in P. digitatum
}

\author{
Loukas Kanetis, Department of Plant Pathology, University of California, Riverside 92521; Helga Förster, De- \\ partment of Plant Pathology, University of California, Davis 95616; and James E. Adaskaveg, Department of Plant \\ Pathology, University of California, Riverside 92521
}

\begin{abstract}
Kanetis, L., Förster, H., and Adaskaveg, J. E. 2008. Baseline sensitivities for new postharvest fungicides against Penicillium spp. on citrus and multiple resistance evaluations in $P$. digitatum. Plant Dis. 92:301-310.

For the first time in over 25 years, three new fungicides (azoxystrobin, fludioxonil, and pyrimethanil), all belonging to different chemical classes, are being registered for postharvest use against Penicillium decays of citrus fruit in the United States. Baseline sensitivities of Penicillium digitatum and P. italicum were developed using isolates collected before the commercial use of these new fungicides. In a comparison of methods, $\mathrm{EC}_{50}$ values obtained using the spiral gradient dilution method were very similar to those obtained using traditional agar dilutions of fungicides. For azoxystrobin, the addition of salicylhydroxamic acid (SHAM) did not significantly affect $\mathrm{EC}_{50}$ values for mycelial growth of both species. In additional studies on conidial germination of $P$. digitatum, SHAM significantly reduced $\mathrm{EC}_{50}$ values for azoxystrobin. For pyrimethanil, the mean $\mathrm{EC}_{50}$ value for mycelial growth obtained using a minimum growth medium for anilinopyrimidine fungicides was significantly lower but comparable to values obtained when using potato dextrose agar. For mycelial growth of $P$. digitatum, mean $\mathrm{EC}_{50}$ values were $0.014,0.025$, and $0.313 \mu \mathrm{g} / \mathrm{ml}$, whereas for conidial germination, they were $0.074,0.163$, and $1.195 \mu \mathrm{g} / \mathrm{ml}$ for azoxystrobin, fludioxonil, and pyrimethanil, respectively. For P. italicum, mean $\mathrm{EC}_{50}$ values for mycelial growth for fludioxonil and pyrimethanil were 0.005 and $0.040 \mu \mathrm{g} / \mathrm{ml}$, respectively. For azoxystrobin, the mean $\mathrm{EC}_{50}$ value for mycelial growth for 33 isolates was $0.029 \mu \mathrm{g} / \mathrm{ml}$. Four isolates had $\mathrm{EC}_{50}$ values $\geq 0.772 \mu \mathrm{g} / \mathrm{ml}$ and were considered part of a resistant subpopulation. Multiple resistance between the older and new postharvest fungicide classes on citrus was not detected in $P$. digitatum, and all isolates that were sensitive or resistant to imazalil or thiabendazole were sensitive to the new compounds. This information is important for monitoring populations of $P$. digitatum, where resistance against the older fungicides has commonly developed.
\end{abstract}

Additional keywords: fungicide resistance

Green mold, caused by the fungus Penicillium digitatum (Pers.:Fr.) Sacc., is a major postharvest decay of citrus fruit in all citrus growing areas of the world, especially in locations with arid and subtropical climates $(6,8)$. Blue mold, caused by $P$. italicum Wehmer, is generally less prevalent, but may become a major problem under conditions that suppress development of green mold such as storage temperatures below $10^{\circ} \mathrm{C}$ (4). Both species of Penicillium mainly infect citrus fruit (6). The reproductive capacity of these fungi is extremely high, and the surface of literally every citrus fruit is contaminated with their airborne spores at harvest time (6). Both fungi are wound-invading pathogens. Conidia of $P$. digitatum have been reported to

Corresponding author: J. E. Adaskaveg

E-mail: jim.adaskaveg@ucr.edu

Accepted for publication 27 September 2007.

doi:10.1094/PDIS-92-2-0301

(c) 2008 The American Phytopathological Society be unable to germinate on and penetrate healthy fruit and can only infect wound sites in the fruit's flavedo (8). Injuries, however, commonly occur during harvesting, transportation, and handling. Applications of effective fungicides soon after harvest can eradicate or inhibit early infections.

In California, both diseases, but especially green mold, may cause significant economic losses to citrus growers and packers. The control of postharvest decays of citrus is based on an integrated program, with the use of sanitation practices and fungicides as core components. Registered postharvest fungicides against Penicillium species and other postharvest pathogens in California include sodium $o$-phenylphenate (SOPP), thiabendazole (TBZ), and imazalil. The former two fungicides have been used routinely by the citrus industry for nearly four decades, while the latter one was first introduced in California in 1981. The extensive use of these fungicides over many years has resulted in the selection and proliferation of fungicideresistant individuals of $P$. digitatum and $P$. italicum. Furthermore, pathogen populations that are resistant to more than one fungicide class (i.e., multiple-resistance) have developed $(5,7,8,14)$.

Until the current registration of new fungicides, there were no effective alternatives to the old compounds, and new fungicides needed to be developed to maintain and improve postharvest disease management. As compared to the introduction of the older fungicides, which took place over decades, the three new compoundsazoxystrobin, fludioxonil, and pyrimethanil-will be registered over a 3 -year period for postharvest use on citrus. These fungicides belong to different chemical classes and have never been used against Penicillium spp. on citrus. This pluralism of postharvest fungicides allows implementation of resistance management practices from the onset of commercial use. Thus, management options for green mold and blue mold will include mixtures and rotations of all registered fungicides, minimizing the risk of resistance development to the new fungicides.

The three new fungicides have different modes of action and different effects on growth of the pathogen. Azoxystrobin is a representative of the broad-spectrum QoI class of fungicides. It is a synthetic compound based on the antifungal molecule strobilurin A (33). Like all strobilurins, azoxystrobin interferes with electron transport during mitochondrial respiration by binding to the ubiquinol oxidation center (Qp) of the mitochondrial cytochrome $b c_{1}$ complex $(2,33)$. Fludioxonil belongs to the phenylpyrroles, a class of nonsystemic compounds derived from the antifungal antibiotic pyrrolnitrin that is produced by bacterial species in the genus Pseudomonas (25). This synthetic fungicide is used to control turfgrass diseases (32) and postharvest decays of stone fruit (10) as well as several seedborne pathogens (12). It inhibits spore germination, germ tube elongation, and mycelial growth (25). It also induces germ tube distortions and cell bursting $(23,25)$. Although the mode of action of fludioxonil is not completely understood, it has been reported to interfere with the osmoregulatory signal transduction pathway by inhibition of a protein kinase in laboratory-selected mutants of Neurospora crassa and other fungi (23). Pyrimethanil is a member of the anilinopyrimidines, another class of fungicides. It 
is effective against diseases caused by Botrytis cinerea on a variety of crops and scab of pome fruits caused by Venturia inaequalis $(18,25)$. Anilinopyrimidine fungicides are thought to interfere with the biosynthesis of methionine and other amino acids and inhibit secretion of hydrolytic enzymes such as pectinases, cellulases, and proteases, but their primary site of action is still unknown (13). Anilinopyrimidines have little effect on spore germination, but strongly inhibit germ tube elongation and mycelial growth (25).

The process of replacing less effective fungicides with new, improved products is difficult due to the high cost of research, development, and registration. Additionally, in order to maintain and extend the effectiveness of new compounds, fungicide resistance must be managed after the fungicide is introduced. An essential component of such management is the periodic monitoring of the target fungal populations for their sensitivity, as is commonly being done in California citrus packinghouses for the older fungicides. Monitoring for the new compounds should be done upon their market introduction in order to detect shifts to lower sensitivities at early stages of selection $(3,16)$. Monitoring should be based upon comparisons of fungal sensitivities with baseline sensitivity data that are determined prior to the commercial introduction of the compounds. For this, reliable and rapid methods have to be employed. The currently most common technique used to determine in vitro toxicity of fungicides is based on measuring mycelial growth or spore germination on culture media amended with serial dilutions of the tested fungicides. Because this technique is laborious and resource intensive, the spiral gradient dilution (SGD) method was developed $(11,15)$.

Thus, the purpose of this study was to develop baseline sensitivity data for $P$. digitatum and $P$. italicum for azoxystrobin, fludioxonil, and pyrimethanil. The specific objectives were to: (i) evaluate the SGD method for the determination of $\mathrm{EC}_{50}$ values of $P$. digitatum isolates by comparison to $\mathrm{EC}_{50}$ values obtained using the serial dilution method; (ii) establish baseline sensitivity ranges of $\mathrm{EC}_{50}$ values for $P$. digitatum and $P$. italicum; (iii) compare the effect of azoxystrobin-specific media to a standard medium in the determination of $\mathrm{EC}_{50}$ values for both species and of pyrimethanil-specific media to a standard medium for P. digitatum; and (iv) evaluate the in vitro potential of multiple-resistance in $P$. digitatum between two of the currently used postharvest fungicides, imazalil and thiabendazole, and the new compounds.

\section{MATERIALS AND METHODS}

Fungicides. Formulated products of azoxystrobin (Abound 2.08F; Syngenta Crop Protection, Greensboro, NC), fludi- oxonil (Scholar 50WP; Syngenta Crop Protection), imazalil (Freshgard 700; FMC Corporation, Philadelphia, PA), and pyrimethanil (Penbotec 400SC; Janssen Pharmaceutica, Titusville, NJ) were used for this study. Thiabendazole (Decco Salt No. 19; Cerexagri-Decco, King of Prussia, PA) was used as technical grade. Aqueous solutions of the fungicides were used in all assays. Stock solutions for thiabendazole were prepared in $95 \%$ ethanol.

Isolates of $\boldsymbol{P}$. digitatum and $\boldsymbol{P}$. italicum and culture methods. Isolates of $P$. digitatum originated from citrus groves and packinghouses throughout the citrus growing areas of California and were collected between 1986 and 1994 (collection of G. J. Holmes) and between 2000 and 2005 (Table 1). To obtain the majority of the total of 67 isolates, we collaborated with three service companies and a citrus growers' cooperative. Multispore isolates were collected on cotton swabs from infected citrus fruit. Isolates of $P$. italicum were obtained from citrus fruit or air samplings in California packinghouses or from fruit in orchards between 2000 and 2005 (Table 2). Isolates were cleaned from contaminants and then single-spored by exponential dilution of a spore suspension using a spiral plater (Autoplate 4000; Spiral Biotech, Norwood, MA). Single-spore isolates were plated out on potato dextrose agar (PDA; Difco Laboratories, Detroit, MI) and incubated for 3 to 4 days until the fungus sporulated. A conidial suspension $(50 \mu \mathrm{l}$ of $1 \times 10^{4}$ conidia $\left./ \mathrm{ml}\right)$ was then evenly spread onto 60-mm PDA plates. Plates were incubated for $24 \mathrm{~h}$, mycelial plugs were transferred into 2-ml microcentrifuge tubes containing $1 \mathrm{ml}$ of sterile water, and tubes were stored at $4^{\circ} \mathrm{C}$ for up to 12 months. These cultures served as working stocks during this study.

Determination of $\mathbf{E C}_{50}$ values for mycelial growth using the agar dilution and SGD methods. Using the agar dilution method, $\mathrm{EC}_{50}$ values for azoxystrobin, fludioxonil, pyrimethanil, and imazalil were determined for seven randomly chosen isolates of $P$. digitatum. Aqueous solutions of fungicides were added to molten PDA after cooling to 45 to $50^{\circ} \mathrm{C}$. Fungicide concentrations used were a series of twofold dilutions from 0.125 to 0.0039 $\mu \mathrm{g} / \mathrm{ml}$ for azoxystrobin and 0.1 to 0.0031 $\mu \mathrm{g} / \mathrm{ml}$ for fludioxonil. For pyrimethanil, concentrations of $0.5,0.30,0.25,0.20$, $0.15,0.10$, and $0.05 \mu \mathrm{g} / \mathrm{ml}$ were used. For imazalil-sensitive and -resistant isolates, imazalil concentrations used were twofold dilutions from 0.1 to $0.0031 \mu \mathrm{g} / \mathrm{ml}$ and 2 to $0.125 \mu \mathrm{g} / \mathrm{ml}$, respectively. Mycelial plugs prepared as described above were placed in the center of $10-\mathrm{cm}$ agar plates. Three replicate plates were used for each fungicide concentration and the nonamended control. Plates were incubated for 5 days at $25^{\circ} \mathrm{C}$. Radial growth was determined as an average of four evenly spaced locations of each fungal colony, and this value was averaged for the three replications of each fungicide concentration evaluated. Percent inhibition for the fungicide-amended plates was calculated based on growth on nonamended control plates (14). $\mathrm{EC}_{50}$ values were determined as described previously (11). This experiment was done three times.

The SGD method was used for all isolates of both species of Penicillium and was conducted as described in detail by Förster et al. (11). Mycelial inoculum for the SGD plates was grown on hydrophilic cellophane strips (du Pont de Nemours, Wilmington, DE). Eight to 10 cellophane strips were placed on the surface of PDA in $10-\mathrm{cm}$ petri dishes, $10 \mu \mathrm{l}$ of a conidial suspension $\left(10^{6}\right.$ conidia/ml $)$ was applied evenly onto each cellophane strip, and strips were incubated at $25^{\circ} \mathrm{C}$ for $24 \mathrm{~h}$. Agar plates $15 \mathrm{~cm}$ in diameter were prepared at least $24 \mathrm{~h}$ before fungicide solutions were applied with a spiral plater using the exponential deposition mode. Concentrations for azoxystrobin, fludioxonil, and pyrimethanil were 100,50 , and $100 \mu \mathrm{g} / \mathrm{ml}$, respectively, for both $P$. digitatum and $P$. italicum. For TBZ and imazalil, concentrations were $200 / 1,000 \mu \mathrm{g} / \mathrm{ml}$ and $30 / 200 \mu \mathrm{g} / \mathrm{ml}$ for sensitive/resistant isolates of $P$. digitatum, whereas concentrations were 500 and $30 \mu \mathrm{g} / \mathrm{ml}$ for isolates of $P$. italicum, respectively. Plates were incubated for 2 to $4 \mathrm{~h}$ to allow fungicides to diffuse into the medium and form a gradient of concentrations along the radius of the plate. Mycelium-covered strips were placed radially along the gradient at predetermined plate positions. For each fungal isolate, a duplicate sample was placed at opposite locations on the plate, and three replicate plates were prepared for each fungicide. The 2-day incubation option was used in the SGE software (Spiral Biotech) for the calculation of the local concentrations where $50 \%$ growth inhibition was observed (11). Molecular weights used for the calculations were 403 for azoxystrobin, 248 for fludioxonil, 297 for imazalil, 199 for pyrimethanil, and 201 for TBZ. Additionally, to evaluate the presence of multiple-resistance in $P$. digitatum between the new fungicides and the older ones (i.e., imazalil and TBZ), a subset of 38 single-spore isolates with a range of sensitivities to imazalil $\left(\mathrm{EC}_{50}\right.$ values from 0.027 to $1.28 \mu \mathrm{g} / \mathrm{ml})$ and $\mathrm{TBZ}\left(\mathrm{EC}_{50}\right.$ values from 0.057 to $\geq 7.825 \mu \mathrm{g} / \mathrm{ml}$ ) were selected (Table 1) for statistical comparisons. All experiments were done three times.

Determination of $\mathbf{E C}_{\mathbf{5 0}}$ values for conidial germination of $\boldsymbol{P}$. digitatum using the SGD method. A subset of $21 P$. digitatum isolates from the baseline population representing different hosts and geographic origins was used (Table 1). Spiral gradient plates were prepared as described above. Concentrations applied to the plates were $100 \mu \mathrm{g} / \mathrm{ml}$ for azoxystrobin, $50 \mu \mathrm{g} / \mathrm{ml}$ for 
Table 1. Isolates of Penicillium digitatum used for development of baseline sensitivities to azoxystrobin, fludioxonil, and pyrimethanil

\begin{tabular}{|c|c|c|c|c|c|c|c|}
\hline \multirow[b]{2}{*}{ No. } & \multirow[b]{2}{*}{ Code no. } & \multirow[b]{2}{*}{ Fruit type } & \multirow[b]{2}{*}{ Location } & \multirow[b]{2}{*}{ County of origin } & \multirow{2}{*}{$\begin{array}{l}\text { Additional } \\
\text { experiments }^{\text {b }}\end{array}$} & \multicolumn{2}{|c|}{ Sensitivity $^{\mathrm{a}}$} \\
\hline & & & & & & Imazalil & TBZ \\
\hline 1 & $1791^{\mathrm{c}}$ & Grapefruit & $\mathrm{NA}^{\mathrm{d}}$ & NA & AP, C, M, MR, SHAM & $\mathrm{R}$ & $\mathrm{S}$ \\
\hline 2 & $\mathrm{~J}-286^{\mathrm{c}}$ & Grapefruit & Orchard & Riverside & $\ldots$ & $\mathrm{S}$ & $\mathrm{S}$ \\
\hline 3 & 439 & Grapefruit & Orchard & Riverside & $\ldots$ & $\mathrm{S}$ & $\mathrm{S}$ \\
\hline 4 & $12 \mathrm{I}$ & Lemon & Packinghouse & Fresno & $\mathrm{AP}, \mathrm{C}, \mathrm{MR}$ & $\mathrm{R}$ & $\mathrm{S}$ \\
\hline 5 & $12 \mathrm{H}$ & Lemon & Packinghouse & Fresno & $\ldots$ & $\mathrm{R}$ & $\mathrm{S}$ \\
\hline 6 & $12 \mathrm{G}$ & Lemon & Packinghouse & Fresno & $\mathrm{AP}, \mathrm{C}$ & $\mathrm{R}$ & $\mathrm{S}$ \\
\hline 7 & $12 \mathrm{~F}$ & Lemon & Packinghouse & Fresno & $\mathrm{AP}$ & $\mathrm{R}$ & $\mathrm{S}$ \\
\hline 8 & $12 \mathrm{E}$ & Lemon & Packinghouse & Fresno & $\mathrm{AP}$ & $\mathrm{R}$ & $\mathrm{S}$ \\
\hline 9 & L1 & Lemon & Packinghouse & Kern & AP, C, M, MR, SHAM & $\mathrm{R}$ & $\mathrm{S}$ \\
\hline 10 & $6 \mathrm{D} 4$ & Lemon & Packinghouse & Kern & MR & $\mathrm{S}$ & $\mathrm{S}$ \\
\hline 11 & 6D3 & Lemon & Packinghouse & Kern & $\ldots$ & $\mathrm{R}$ & $\mathrm{R}$ \\
\hline 12 & $6 \mathrm{D} 2$ & Lemon & Packinghouse & Kern & MR & $\mathrm{R}$ & $\mathrm{R}$ \\
\hline 13 & 6D1 & Lemon & Packinghouse & Kern & $\ldots$ & $\mathrm{R}$ & $\mathrm{R}$ \\
\hline 14 & $6 \mathrm{C} 4$ & Lemon & Packinghouse & Kern & MR & $\mathrm{R}$ & $\mathrm{R}$ \\
\hline 15 & $6 \mathrm{C} 3$ & Lemon & Packinghouse & Kern & MR & $\mathrm{R}$ & $\mathrm{R}$ \\
\hline 16 & $6 \mathrm{C} 2$ & Lemon & Packinghouse & Kern & MR & $\mathrm{S}$ & $\mathrm{R}$ \\
\hline 17 & $6 \mathrm{C} 1$ & Lemon & Packinghouse & Kern & MR & $\mathrm{R}$ & $\mathrm{R}$ \\
\hline 18 & $6 \mathrm{~B} 3$ & Lemon & Packinghouse & Kern & MR & $\mathrm{S}$ & $\mathrm{R}$ \\
\hline 19 & $6 \mathrm{~B} 2$ & Lemon & Packinghouse & Kern & MR & $\mathrm{S}$ & $\mathrm{S}$ \\
\hline 20 & $6 \mathrm{~B} 1$ & Lemon & Packinghouse & Kern & MR & $\mathrm{S}$ & $\mathrm{S}$ \\
\hline 21 & $6 \mathrm{~A} 1$ & Lemon & Packinghouse & Kern & MR & $\mathrm{S}$ & $\mathrm{S}$ \\
\hline 22 & 5D1 & Lemon & Packinghouse & Kern & MR & $\mathrm{R}$ & $\mathrm{R}$ \\
\hline 23 & $5 \mathrm{C} 3$ & Lemon & Packinghouse & Kern & MR & $\mathrm{R}$ & $\mathrm{R}$ \\
\hline 24 & $5 \mathrm{C} 2$ & Lemon & Packinghouse & Kern & MR & $\mathrm{S}$ & $\mathrm{R}$ \\
\hline 25 & $5 \mathrm{~B} 3$ & Lemon & Packinghouse & Kern & MR & $\mathrm{R}$ & $\mathrm{R}$ \\
\hline 26 & $5 \mathrm{~A} 1$ & Lemon & Orchard & Kern & MR & $\mathrm{S}$ & $\mathrm{S}$ \\
\hline 27 & $1 \mathrm{E}$ & Lemon & Packinghouse & Kern & $\mathrm{MR}$ & $\mathrm{R}$ & $\mathrm{R}$ \\
\hline 28 & 2152 & Lemon & Packinghouse & Kern & AP, C, M, MR, SHAM & $\mathrm{R}$ & $\mathrm{R}$ \\
\hline 29 & $\mathrm{~J}-235^{\mathrm{c}}$ & Lemon & Packinghouse & Los Angeles & $\ldots$ & $\mathrm{R}$ & $\mathrm{S}$ \\
\hline 30 & $\mathrm{~J}-227^{\mathrm{c}}$ & Lemon & Packinghouse & Los Angeles & $\ldots$ & $\mathrm{R}$ & $\mathrm{S}$ \\
\hline 31 & $1726^{c}$ & Lemon & Orchard & Riverside & AP, C, M, MR, SHAM & $\mathrm{S}$ & $\mathrm{S}$ \\
\hline 32 & $\mathrm{Pd}$ & Lemon & Orchard & Riverside & AP, C, M, MR, SHAM & $\mathrm{S}$ & $\mathrm{S}$ \\
\hline 33 & $\mathrm{H}$ & Lemon & Orchard & Riverside & AP, C, M, MR, SHAM & $\mathrm{S}$ & $\mathrm{S}$ \\
\hline 34 & $\mathrm{~J}-348^{\mathrm{c}}$ & Lemon & Orchard & San Bernardino & $\ldots$ & $\mathrm{S}$ & $\mathrm{S}$ \\
\hline 35 & $\mathrm{P} 4^{\mathrm{c}}$ & Lemon & Packinghouse & Tulare & $\ldots$ & $\mathrm{R}$ & $\mathrm{S}$ \\
\hline 36 & $2 \mathrm{~A}$ & Lemon & Packinghouse & Tulare & MR & $\mathrm{R}$ & $\mathrm{S}$ \\
\hline 37 & $1 \mathrm{D}$ & Lemon & Packinghouse & Tulare & $\mathrm{C}$ & $\mathrm{R}$ & $\mathrm{S}$ \\
\hline 38 & $12 \mathrm{D}$ & Lemon & Packinghouse & Tulare & $\mathrm{AP}, \mathrm{MR}$ & $\mathrm{R}$ & $\mathrm{S}$ \\
\hline 39 & $12 \mathrm{C}$ & Lemon & Packinghouse & Tulare & AP, MR & $\mathrm{R}$ & $\mathrm{S}$ \\
\hline 40 & $12 \mathrm{~B}$ & Lemon & Packinghouse & Tulare & $\mathrm{AP}, \mathrm{MR}$ & $\mathrm{R}$ & $\mathrm{S}$ \\
\hline 41 & $12 \mathrm{~A}$ & Lemon & Packinghouse & Tulare & $\mathrm{AP}, \mathrm{MR}$ & $\mathrm{R}$ & $\mathrm{S}$ \\
\hline 42 & $J-976^{c}$ & Lemon & Packinghouse & Ventura & $\ldots$ & $\mathrm{R}$ & $\mathrm{ND}^{\mathrm{e}}$ \\
\hline 43 & J-616 & Lemon & Packinghouse & Ventura & $\ldots$ & $\mathrm{R}$ & ND \\
\hline 44 & $\mathrm{~J}-125^{\mathrm{c}}$ & Lemon & Packinghouse & Ventura & $\ldots$ & $\mathrm{R}$ & $\mathrm{S}$ \\
\hline 45 & 4D & Lemon & Packinghouse & Ventura & $\ldots$ & $\mathrm{R}$ & $\mathrm{S}$ \\
\hline 46 & $4 \mathrm{C}$ & Lemon & Packinghouse & Ventura & $\ldots$ & $\mathrm{R}$ & $\mathrm{S}$ \\
\hline 47 & $4 B$ & Lemon & Packinghouse & Ventura & $\ldots$ & $\mathrm{R}$ & $\mathrm{S}$ \\
\hline 48 & $4 \mathrm{~A}$ & Lemon & Packinghouse & Ventura & MR & $\mathrm{R}$ & $\mathrm{S}$ \\
\hline 49 & $3 B$ & Lemon & Packinghouse & Ventura & $\mathrm{C}, \mathrm{MR}$ & $\mathrm{R}$ & $\mathrm{S}$ \\
\hline 50 & $3 \mathrm{~A}$ & Lemon & Packinghouse & Ventura & $\mathrm{C}, \mathrm{MR}$ & $\mathrm{R}$ & $\mathrm{S}$ \\
\hline 51 & 1792 & Lemon & Packinghouse & Ventura & AP, C, M, MR, SHAM & $\mathrm{R}$ & $\mathrm{S}$ \\
\hline 52 & $\mathrm{~J}-893^{\mathrm{c}}$ & Orange & Packinghouse & Fresno & $\ldots$ & $\mathrm{R}$ & ND \\
\hline 53 & $1 \mathrm{C}$ & Orange & Packinghouse & Fresno & $\mathrm{C}, \mathrm{MR}$ & $\mathrm{S}$ & $\mathrm{S}$ \\
\hline 54 & 1B & Orange & Packinghouse & Fresno & $\mathrm{C}, \mathrm{MR}$ & $\mathrm{S}$ & $\mathrm{S}$ \\
\hline 55 & $1 \mathrm{~A}$ & Orange & Packinghouse & Fresno & $\mathrm{C}, \mathrm{MR}$ & $\mathrm{S}$ & $\mathrm{S}$ \\
\hline 56 & $8 \mathrm{~F}$ & Orange & Packinghouse & Tulare & $\mathrm{AP}, \mathrm{C}$ & $\mathrm{R}$ & $\mathrm{S}$ \\
\hline 57 & $8 \mathrm{E}$ & Orange & Packinghouse & Tulare & $\mathrm{AP}, \mathrm{C}, \mathrm{MR}$ & $\mathrm{R}$ & $\mathrm{S}$ \\
\hline 58 & $8 \mathrm{D}$ & Orange & Packinghouse & Tulare & $\mathrm{AP}$ & $\mathrm{R}$ & $\mathrm{S}$ \\
\hline 59 & $8 \mathrm{C}$ & Orange & Packinghouse & Tulare & $\mathrm{AP}, \mathrm{C}$ & $\mathrm{S}$ & $\mathrm{S}$ \\
\hline 60 & $8 B$ & Orange & Packinghouse & Tulare & $\mathrm{AP}, \mathrm{C}$ & $\mathrm{R}$ & $\mathrm{R}$ \\
\hline 61 & $8 \mathrm{~A}$ & Orange & Packinghouse & Tulare & $\mathrm{AP}, \mathrm{C}$ & $\mathrm{R}$ & $\mathrm{S}$ \\
\hline 62 & $2 \mathrm{~B}$ & Orange & Packinghouse & Tulare & MR & $\mathrm{S}$ & $\mathrm{S}$ \\
\hline 63 & $\mathrm{~J}-713^{\mathrm{c}}$ & Orange & Packinghouse & Ventura & $\ldots$ & $\mathrm{R}$ & ND \\
\hline 64 & 373 & Orange & Packinghouse & Yuma & $\ldots$ & $\mathrm{S}$ & $\mathrm{S}$ \\
\hline 65 & $\mathrm{P} 2^{\mathrm{c}}$ & Orange & NA & Fresno & $\ldots$ & $\mathrm{S}$ & $\mathrm{S}$ \\
\hline 66 & $1 \mathrm{~F}^{\mathrm{c}}$ & NA & Orchard & NA & $\mathrm{C}, \mathrm{MR}$ & $\mathrm{S}$ & $\mathrm{S}$ \\
\hline 67 & $\mathrm{P} 3 \mathrm{~F}^{\mathrm{c}}$ & NA & NA & NA & $\ldots$ & $\mathrm{S}$ & $\mathrm{S}$ \\
\hline
\end{tabular}

a Sensitivity to imazalil and thiabendazole (TBZ) was determined using the spiral gradient dilution (SGD) method: $\mathrm{S}=$ sensitive or $\mathrm{R}=$ resistant to the respective fungicide. For imazalil, resistance was considered at $\mathrm{EC}_{50} \geq 0.15 \mu \mathrm{g} / \mathrm{ml}$; for $\mathrm{TBZ}_{\text {at }} \mathrm{EC}_{50} \geq 1 \mu \mathrm{g} / \mathrm{ml}$.

b Isolates used for additional experiments: AP = effect of anilinopyrimidine (AP) medium on effective concentrations to inhibit mycelial growth by $50 \%$ ( $\mathrm{EC}_{50}$ values) for pyrimethanil; $\mathrm{C}=$ conidial germination studies; $\mathrm{M}=$ comparison between agar dilution and spiral gradient dilution (SGD) method; $\mathrm{MR}=$ multiple-resistance studies; and SHAM = effect of salicylhydroxamic acid (SHAM) on $\mathrm{EC}_{50}$ values of azoxystrobin.

${ }^{\mathrm{c}}$ Isolates from the collection of G. J. Holmes.

d Information not available (NA).

e Not determined (ND). 
fludioxonil, and $200 \mu \mathrm{g} / \mathrm{ml}$ for pyrimethanil. For azoxystrobin, either PDA or PDA amended with $100 \mu \mathrm{g} / \mathrm{ml}$ salicylhydroxamic acid (SHAM; prepared in 50\% ethanol and added to the cooled media) was used. A conidial suspension $\left(10^{6}\right.$ conidia/ml) was prepared from 6- to 8-dayold cultures, and $10 \mu \mathrm{l}$ was streaked radially along the concentration gradient (11). After incubation at $25^{\circ} \mathrm{C}$ for 16 to 18 $\mathrm{h}$, conidial germination was evaluated under an inverted microscope (Axiovert S100; Carl Zeiss, Jena, Germany) using the $20 \times$ objective. A conidium was considered germinated if the germ tube was at least twice the diameter of the conidium. The location along the spore streak where germination was inhibited by $50 \%$ was determined by counting conidia within the field of view and was marked on the bottom side of the plate. The 1-day incubation option was used in the SGE software for this assay. Experiments were conducted three times.

Effect of SHAM and different culture media on $\mathbf{E C}_{50}$ values in mycelial growth assays of azoxystrobin and pyrimethanil, respectively. Sensitivities to azoxystrobin were determined for seven isolates of $P$. digitatum as indicated in Table 3 and for 33 isolates of $P$. italicum (Table 4) using the agar dilution method. For this, either PDA amended with azoxystrobin or PDA amended with azoxystrobin and 100 $\mu \mathrm{g} \quad \mathrm{SHAM} / \mathrm{ml}$ was used as described above. $\mathrm{EC}_{50}$ values and percent inhibition of mycelial growth at $0.25 \mu \mathrm{g}$ azoxystrobin/ml (done only for $P$. digitatum) in each of the two media as compared with the nonamended control medium were determined.

The anilinopyrimidine (AP) working group of the Fungicide Resistance Action Committee (FRAC) has suggested the use of a synthetic medium for mycelial growth assays that contains $10 \mathrm{~g}$ glucose, $1.5 \mathrm{~g}$ $\mathrm{K}_{2} \mathrm{HPO}_{4}, 2 \mathrm{~g} \mathrm{KH}_{2} \mathrm{PO}_{4}, 1 \mathrm{~g}\left(\mathrm{NH}_{4}\right)_{2} \mathrm{SO}_{4}, 0.5 \mathrm{~g}$ $\mathrm{MgSO}_{4} \cdot 7 \mathrm{H}_{2} \mathrm{O}$, and $12.5 \mathrm{~g}$ of agar per liter of distilled water $(13,19)$. Thus, $\mathrm{EC}_{50}$ values for mycelial growth for a subset of 21 baseline isolates of $P$. digitatum (Table 1) were also determined using this FRAC-AP medium in the SGD assay as described above. $\mathrm{EC}_{50}$ values and percent inhibition of mycelial growth at $0.35 \mu \mathrm{g}$ pyrimethanil $/ \mathrm{ml}$ in each of the two media as compared with the nonamended control medium were determined. The experiments for these media comparisons with azoxystrobin and pyrimethanil were done three times.
Statistical analysis of data. For repeated experiments, the homogeneity of variances was tested using Bartlett's test of homogeneity. Because variances were homogeneous for each experiment, data were combined and further statistically analyzed. For the comparison of the agar dilution and SGD methods, average $\mathrm{EC}_{50}$ values obtained by the SGD method were regressed against values obtained using the agar dilution method using SAS version 9.1 (SAS Institute, Cary, NC). The slope and intercept of the regression line were compared by means of $t$ tests to a theoretical 1:1 relationship between the two methods with a slope of 1 and an intercept of zero (11). The accuracy of the SGD method was measured by estimating bias, which is defined as $100 \times(\beta-1)$, where $\beta$ is the slope of the linear regression. The precision of the method was estimated by calculating the coefficient of variation or $\mathrm{CV}\left(100 \times \mathrm{s}_{\beta} / \beta\right)$ and a confidence interval or CI $\left(\beta \pm s_{\beta} t_{\mathrm{df} 0.05}\right)$, where $s_{\beta}$ is the standard error of the slope estimate, and $t_{\mathrm{df} 0.05}$ is the upper fifth percentile of a $t$ distribution with df degrees of freedom (11).

Mean $\mathrm{EC}_{50}$ values of the baseline populations of $P$. digitatum and $P$. italicum for the three new fungicides were plotted in

Table 2. Isolates of Penicillium italicum used for development of baseline sensitivities to azoxystrobin, fludioxonil, and pyrimethanil

\begin{tabular}{|c|c|c|c|c|c|c|}
\hline \multirow[b]{2}{*}{ No. } & \multirow[b]{2}{*}{ Code no. } & \multirow{2}{*}{$\begin{array}{l}\text { Source of isolation/ } \\
\text { fruit type }\end{array}$} & \multirow[b]{2}{*}{ Location } & \multirow[b]{2}{*}{ County of origin } & \multicolumn{2}{|c|}{ Sensitivities $^{\mathbf{a}}$} \\
\hline & & & & & Imazalil & TBZ \\
\hline 1 & $2 \mathrm{AY}$ & Air-sampling & Packinghouse & Riverside & $\mathrm{S}$ & $\mathrm{S}$ \\
\hline 2 & $2 \mathrm{P} 2$ & Air-sampling & Packinghouse & Riverside & $\mathrm{S}$ & $\mathrm{S}$ \\
\hline 3 & $6 \mathrm{CCH}$ & Air-sampling & Packinghouse & Riverside & $\mathrm{S}$ & $\mathrm{S}$ \\
\hline 4 & $6 \mathrm{CY}$ & Air-sampling & Packinghouse & Riverside & $\mathrm{S}$ & $\mathrm{S}$ \\
\hline 5 & PI1 & Air-sampling & Packinghouse & Riverside & $\mathrm{S}$ & $\mathrm{S}$ \\
\hline 6 & L1A & Lemon & Packinghouse & Riverside & $\mathrm{S}$ & $\mathrm{S}$ \\
\hline 7 & L1B & Lemon & Packinghouse & Riverside & $\mathrm{S}$ & $\mathrm{S}$ \\
\hline 8 & L2B & Lemon & Packinghouse & Riverside & $\mathrm{S}$ & $\mathrm{S}$ \\
\hline 9 & L3A & Lemon & Packinghouse & Riverside & $\mathrm{S}$ & $\mathrm{S}$ \\
\hline 10 & L5B & Lemon & Packinghouse & Riverside & $\mathrm{S}$ & $\mathrm{S}$ \\
\hline 35 & $24 \mathrm{E}$ & Lemon & Packinghouse & Riverside & $\mathrm{S}$ & $\mathrm{S}$ \\
\hline 37 & $9 \mathrm{D}$ & Lemon & Packinghouse & Riverside & $\mathrm{S}$ & $\mathrm{S}$ \\
\hline 22 & KOR1688 & Orange & Orchard & Fresno & $\mathrm{S}$ & $\mathrm{S}$ \\
\hline 24 & KOR1734 & Orange & Orchard & Fresno & $\mathrm{S}$ & $\mathrm{S}$ \\
\hline 27 & KOR 1876 & Orange & Orchard & Fresno & $\mathrm{S}$ & $\mathrm{S}$ \\
\hline 29 & KOR2010 & Orange & Orchard & Fresno & $\mathrm{S}$ & $\mathrm{S}$ \\
\hline 34 & 305 & Orange & Orchard & Fresno & $\mathrm{S}$ & $\mathrm{S}$ \\
\hline 36 & $1 \mathrm{~A}$ & Orange & Packinghouse & Fresno & $\mathrm{S}$ & $\mathrm{S}$ \\
\hline 31 & KOR2073 & Orange & Orchard & Kern & $\mathrm{S}$ & $\mathrm{S}$ \\
\hline 11 & $\mathrm{O} 2 \mathrm{~A}$ & Orange & Packinghouse & Riverside & $\mathrm{S}$ & $\mathrm{S}$ \\
\hline 12 & O4A & Orange & Packinghouse & Riverside & $\mathrm{S}$ & $\mathrm{S}$ \\
\hline 13 & O4B & Orange & Packinghouse & Riverside & $\mathrm{S}$ & $\mathrm{S}$ \\
\hline 14 & O5 & Orange & Packinghouse & Riverside & $\mathrm{S}$ & $\mathrm{S}$ \\
\hline 15 & O7A & Orange & Packinghouse & Riverside & $\mathrm{S}$ & $\mathrm{S}$ \\
\hline 16 & OP14 & Orange & Packinghouse & Riverside & $\mathrm{S}$ & $\mathrm{S}$ \\
\hline 32 & $20 \mathrm{~L}$ & Orange & Packinghouse & San Bernardino & $\mathrm{S}$ & $\mathrm{S}$ \\
\hline 17 & KOR1483 & Orange & Orchard & Tulare & $\mathrm{S}$ & $\mathrm{S}$ \\
\hline 18 & KOR1505 & Orange & Orchard & Tulare & $\mathrm{S}$ & $\mathrm{S}$ \\
\hline 19 & KOR1572 & Orange & Orchard & Tulare & $\mathrm{S}$ & $\mathrm{S}$ \\
\hline 20 & KOR1642 & Orange & Orchard & Tulare & $\mathrm{S}$ & $\mathrm{S}$ \\
\hline 21 & KOR1671 & Orange & Orchard & Tulare & $\mathrm{S}$ & $\mathrm{S}$ \\
\hline 23 & KOR 1727 & Orange & Orchard & Tulare & $\mathrm{S}$ & $\mathrm{S}$ \\
\hline 25 & KOR 1775 & Orange & Orchard & Tulare & $\mathrm{S}$ & $\mathrm{S}$ \\
\hline 26 & KOR1795 & Orange & Orchard & Tulare & $\mathrm{S}$ & $\mathrm{S}$ \\
\hline 28 & KOR1935 & Orange & Orchard & Tulare & $\mathrm{S}$ & $\mathrm{S}$ \\
\hline 30 & KOR2055 & Orange & Orchard & Tulare & $\mathrm{S}$ & $\mathrm{S}$ \\
\hline 33 & 742 & Orange & Orchard & Tulare & $\mathrm{S}$ & $\mathrm{S}$ \\
\hline
\end{tabular}

\footnotetext{
${ }^{a}$ Isolates were considered sensitive at $\mathrm{EC}_{50}<0.041 \mu \mathrm{g}$ imazalil $/ \mathrm{ml}$, or at $\mathrm{EC}_{50}<0.12 \mu \mathrm{g}$ thiabendazole $(\mathrm{TBZ}) / \mathrm{ml}$.
} 
frequency histograms. For this, $\mathrm{EC}_{50}$ values were first $\log _{10}$-transformed and the bin (i.e., $\mathrm{EC}_{50}$ category) width $h$ for the transformed data was determined using the method of Scott (26) with the equation:

$$
h_{n}=3.49 s n^{-1 / 3}
$$

where $s$ is an estimate of the standard deviation and $n$ is the number of isolates used for each fungicide evaluated. Standard deviations were calculated from mean $\log _{10}$-transformed $\mathrm{EC}_{50}$ values for all isolates used in each fungicide evaluation. The number of bins was then determined over the range of $\mathrm{EC}_{50}$ values for each fungicide.

For the comparisons of the toxicity of azoxystrobin in SHAM-amended and nonamended media and for the comparison of the toxicity of pyrimethanil on different culture media, mean $\mathrm{EC}_{50}$ values were compared using analysis of variance (ANOVA) and least significant difference (LSD) separation procedures of SAS. Similarly, arcsine transformed percent inhibition values were compared for each fungicide at equivalent concentrations for the two media using ANOVA and LSD mean separation procedures. To determine if multiple-resistance between old (i.e., TBZ and imazalil) and each of the new fungicides was present, mean $\mathrm{EC}_{50}$ values were plotted in pair-wise comparisons. $\mathrm{EC}_{50}$ values of each of the new fungicides were then regressed against those obtained for imazalil or TBZ using ANOVA and regression procedures of SAS.

\section{RESULTS}

Comparison of $\mathrm{EC}_{50}$ values for $P$. digitatum using the agar dilution and SGD methods. The regression of $\mathrm{EC}_{50}$ values for mycelial growth determined by the agar dilution method on values obtained by the SGD method is shown in Figure 1. The model for the regression was highly significant $(P<0.01)$, and the coefficient of determination $\left(r^{2}\right)$ was 0.94 . The slope of the regression line was not significantly different $(P=0.97)$ from the slope of a 1:1 relationship between the two methods. Furthermore, accuracy of the method was measured by the estimation of bias $(b)$. This value was -1.87 , and thus the SGD method underestimated a $1: 1$ relationship by $1.87 \%$. The CV and CI, statistical estimates of the precision of a test, were $4.9 \%$ and $0.98 \pm 0.08$, respectively.

Baseline sensitivity for mycelial growth and conidial germination using the SGD assay. $\mathrm{EC}_{50}$ values for mycelial growth were determined for both species of Penicillium, whereas values for conidial germination were only determined for $P$. digitatum. Mean $\mathrm{EC}_{50}$ values for mycelial growth of the 67 isolates of $P$. digitatum for azoxystrobin, fludioxonil, and pyrimethanil using the SGD method were $0.014,0.025$, and $0.313 \mu \mathrm{g} / \mathrm{ml}$, respectively. Ranges of $\mathrm{EC}_{50}$ values were from 0.007 to $0.028 \mu \mathrm{g} / \mathrm{ml}$ for azoxystrobin, from 0.009 to $0.072 \mu \mathrm{g} / \mathrm{ml}$ for fludioxonil, and from 0.208 to $0.413 \mu \mathrm{g} / \mathrm{ml}$ for pyrimethanil. The frequency distribution of $\mathrm{EC}_{50}$ categories for each fungicide is shown in the histograms of Figure 2A to C.

For the 37 isolates of $P$. italicum, mean $\mathrm{EC}_{50}$ values for mycelial growth for fludioxonil and pyrimethanil using the SGD method were 0.005 and $0.040 \mu \mathrm{g} / \mathrm{ml}$, respectively. Ranges of $\mathrm{EC}_{50}$ values were from 0.004 to $0.010 \mu \mathrm{g} / \mathrm{ml}$ for fludioxonil and from 0.010 to $0.082 \mu \mathrm{g} / \mathrm{ml}$ for pyrimethanil. For azoxystrobin, the mean $\mathrm{EC}_{50}$ value for mycelial growth for 33 isolates was $0.029 \mu \mathrm{g} / \mathrm{ml}$ with a range from 0.020 to $0.043 \mu \mathrm{g} / \mathrm{ml}$. Four isolates had $\mathrm{EC}_{50}$ values $\geq 0.772 \mu \mathrm{g} / \mathrm{ml}$. The frequency distribution of $\mathrm{EC}_{50}$ categories for each fungicide is shown in the histograms of Figure $3 \mathrm{~A}$ to $\mathrm{C}$. The histogram for azoxystrobin does not include the four insensitive isolates. The histogram developed for all isolates only had two bins (i.e., sensitive, $n=33$; and insensitive isolates, $n=$ 4). Scott's number for bin width using all isolates was 0.476 , whereas for the sensitive isolates this value was 0.089 . In comparing mean $\mathrm{EC}_{50}$ values of the two pathogens, $P$. italicum was less sensitive to azoxystrobin, but more sensitive to fludioxonil and pyrimethanil than $P$. digitatum.

$\mathrm{EC}_{50}$ values for conidial germination were determined for 21 single-spore isolates of $P$. digitatum. For azoxystrobin, no inhibition of conidial germination was observed on PDA without the addition of SHAM at any concentration of the fungicide evaluated. On SHAM-amended PDA, the range of $\mathrm{EC}_{50}$ values was between 0.047 and $0.166($ mean $=0.074) \mu \mathrm{g}$ azoxystrobin/ml. $\mathrm{EC}_{50}$ values ranged between 0.106 and 0.204 (mean $=0.163) \mu \mathrm{g} / \mathrm{ml}$ for fludioxonil and between 0.863 and 1.608 $($ mean $=1.195) \mu \mathrm{g} / \mathrm{ml}$ for pyrimethanil. The frequency distribution of $\mathrm{EC}_{50}$ categories for each fungicide is shown in the histograms of Figure 4A to C.

Effect of SHAM and different culture media on $\mathrm{EC}_{50}$ values for mycelial

Table 4. Effect of salicylhydroxamic acid on the effective concentration of azoxystrobin to inhibit mycelial growth of Penicillium italicum by $50 \%$

\begin{tabular}{|c|c|c|c|c|c|c|}
\hline \multirow[b]{2}{*}{ Method $^{\mathrm{a}}$} & \multirow[b]{2}{*}{ Fungicide } & \multirow[b]{2}{*}{ Treatment $^{b}$} & \multirow{2}{*}{$\begin{array}{l}\text { No. of } \\
\text { isolates }\end{array}$} & \multirow{2}{*}{$\begin{array}{c}\text { Mean } E C_{50} \\
\text { values } \\
(\mu \mathrm{g} / \mathrm{ml})^{\mathbf{c}}\end{array}$} & \multicolumn{2}{|c|}{ Statistics $^{d}$} \\
\hline & & & & & LSD & $P>\mathbf{F}$ \\
\hline \multirow[t]{2}{*}{$\overline{S G D}$} & Azoxystrobin & + SHAM & 34 & 0.031 & A & 0.06 \\
\hline & Azoxystrobin & - SHAM & 34 & 0.029 & A & \\
\hline
\end{tabular}

${ }^{a}$ Spiral gradient dilution (SGD) method was used.

${ }^{b}$ Potato dextrose agar (PDA) was amended (+) or not amended (-) with salicylhydroxamic acid (SHAM) at $100 \mu \mathrm{g} / \mathrm{ml}$.

${ }^{\mathrm{c}}$ Mean $\mathrm{EC}_{50}$ values are averages from three experiments.

${ }^{\mathrm{d}}$ Mean values followed by the same letter are not significantly different according to analysis of variance and least significant difference (LSD) mean separation procedures $(P>0.05)$.

Table 3. Effect of salicylhydroxamic acid and different culture media on the in vitro toxicity of azoxystrobin and pyrimethanil, respectively, to mycelial growth of Penicillium digitatum

\begin{tabular}{|c|c|c|c|c|c|c|c|c|c|}
\hline \multirow[b]{3}{*}{ Method $^{\mathrm{a}}$} & \multirow[b]{3}{*}{ Fungicide } & \multirow[b]{3}{*}{ Treatment $^{\mathrm{b}}$} & \multirow{3}{*}{$\begin{array}{l}\text { No. of } \\
\text { isolates }\end{array}$} & \multicolumn{6}{|c|}{ Mycelial growth assays } \\
\hline & & & & \multirow{2}{*}{$\begin{array}{c}\text { Mean } E C_{50} \\
\text { values } \\
(\mu \mathrm{g} / \mathrm{ml})^{\mathrm{c}}\end{array}$} & \multicolumn{2}{|c|}{ Statistics $^{\mathrm{d}}$} & \multirow{2}{*}{$\begin{array}{l}\text { Inhibition }(\%) \\
\text { at equivalent } \\
\text { concentrations }\end{array}$} & \multicolumn{2}{|c|}{ Statistics $^{d}$} \\
\hline & & & & & LSD & $P>\mathbf{F}$ & & LSD & $P>F$ \\
\hline \multirow[t]{2}{*}{ Agar dilution } & Azoxystrobin & + SHAM & 7 & 0.023 & A & 0.1315 & 99 & A & $<0.0001$ \\
\hline & Azoxystrobin & - SHAM & 7 & 0.028 & A & & 83.5 & B & \\
\hline \multirow[t]{2}{*}{ SGD } & Pyrimethanil & PDA & 21 & 0.31 & A & $<0.0001$ & 99 & A & 0.0653 \\
\hline & Pyrimethanil & AP & 21 & 0.21 & B & & 95.6 & A & \\
\hline
\end{tabular}

a Agar dilution and spiral gradient dilution (SGD) methods were used.

${ }^{\mathrm{b}}$ For azoxystrobin, potato dextrose agar (PDA) was amended (+) or not amended (-) with salicylhydroxamic acid (SHAM) at $100 \mu \mathrm{g} / \mathrm{ml}$. For pyrimethanil, an anilinopyrimidine (AP) minimal medium $(13,19)$ was compared to PDA.

${ }^{\mathrm{c}}$ Mean $\mathrm{EC}_{50}$ values are the averages from three experiments.

${ }^{\mathrm{d}}$ Mean values followed by the same letter are not significantly different according to an analysis of variance and least significant difference (LSD) mean separation procedures $(P>0.05)$.

${ }^{\mathrm{e}}$ Inhibition at equivalent concentrations for the two media in each comparison was determined using $0.25 \mu \mathrm{g}$ azoxystrobin/ml or $0.35 \mu \mathrm{g}$ pyrimethanil/ml and was based on growth on nonamended control media. 
growth of azoxystrobin and pyrimethanil, respectively. The effect of SHAM on $\mathrm{EC}_{50}$ values of azoxystrobin was determined for both species of Penicillium, whereas the effect of culture media on $\mathrm{EC}_{50}$ values of pyrimethanil was only determined for $P$. digitatum. The mean $\mathrm{EC}_{50}$ value for azoxystrobin using PDA without SHAM was $0.028 \mu \mathrm{g} / \mathrm{ml}$ for $P$. digitatum, whereas it was $0.023 \mu \mathrm{g} / \mathrm{ml}$ when SHAM was added to the medium. In statistical comparisons of the values, the model was not significant $(P=0.1315)$ and the means did not separate using the LSD test (Table $3)$. On the PDA-SHAM medium at $0.25 \mu \mathrm{g}$ azoxystrobin $/ \mathrm{ml}$, fungal growth was inhibited by $99 \%$ as compared to the control. At the same concentration of azoxystrobin on nonamended PDA, inhibition was significantly less (i.e., $85 \%$ ) as compared to the medium amended with SHAM (Table 3), and higher concentrations of azoxystrobin did not further reduce growth. For P. italicum, also no significant differences in mean $\mathrm{EC}_{50}$ values were obtained using PDA without or with the addition of SHAM (Table 4).

For pyrimethanil, $\mathrm{EC}_{50}$ values of 21 isolates of $P$. digitatum were compared using PDA and AP media. Using the AP medium, values ranged from 0.14 to $0.25 \mu \mathrm{g} / \mathrm{ml}$, whereas on PDA values ranged from 0.25 to $0.40 \mu \mathrm{g} / \mathrm{ml}$. The ANOVA model in comparisons of the values was highly significant $(P<0.0001)$, and mean $\mathrm{EC}_{50}$ values were significantly different (Table 3). Additionally, mycelial growth was reduced on AP medium as compared with PDA. On PDA, an incubation time of 3 days was sufficient for mycelial growth to be accurately measured, whereas on AP medium 5 to 6 days were required. Using either medium at $0.35 \mu \mathrm{g}$ pyrimethanil $/ \mathrm{ml}$ (i.e., the concentration of pyrimethanil where growth on PDA was inhibited by $99 \%$ ), fungal growth was inhibited similarly and mean values of percent inhibi- tion were not significantly different (Table 3).

Evaluation of multiple-resistance in $\boldsymbol{P}$. digitatum. In multiple-resistance studies, 38 isolates that were either sensitive or resistant to imazalil or TBZ were used. In pair-wise comparisons, mean $\mathrm{EC}_{50}$ values for imazalil for each isolate were regressed on values for each of the new fungicides. In Figure 5A to $\mathrm{C}$, sensitive isolates, isolates resistant to only imazalil or TBZ, and isolates with multiple-resistance to imazalil and TBZ are shown as different symbols. There was no significant correlation between the sensitivities to imazalil and $\mathrm{EC}_{50}$ values of the new postharvest fungicides. More specifically, $P$ values and coefficients of determination for each fungicide were: $P=0.05$ and $r^{2}=0.12$ for azoxystrobin; $P=0.08$ and $r^{2}=0.10$ for fludioxonil; and $P=0.45$ and $r^{2}=0.02$ for pyrimethanil as shown in Figure $5 \mathrm{~A}, \mathrm{~B}$, and $\mathrm{C}$, respectively. $\mathrm{EC}_{50}$ values for isolates resistant to TBZ could not be determined because values exceeded the solubility of the fungicide in the aqueous agar. Thus, regressions were not performed. Still, isolates resistant to TBZ were all sensitive and were found across the entire range of baseline sensitivities for each of the new fungicides (data not shown).

\section{DISCUSSION}

This is the first study to present baseline sensitivities of $P$. digitatum and $P$. italicum populations to the new citrus postharvest fungicides azoxystrobin, fludioxonil, and pyrimethanil. In vitro sensitivities for azoxystrobin have never been previously reported for any postharvest pathogen. For fludioxonil, Errampalli (9) determined mean $\mathrm{EC}_{50}$ values for mycelial growth and conidial germination of seven isolates of $P$. expansum to be 0.018 and $0.094 \mu \mathrm{g} / \mathrm{ml}$, respectively. Förster et al. $(10,11)$ found similar in vitro sensitivities for mycelial growth of the postharvest pathogens of

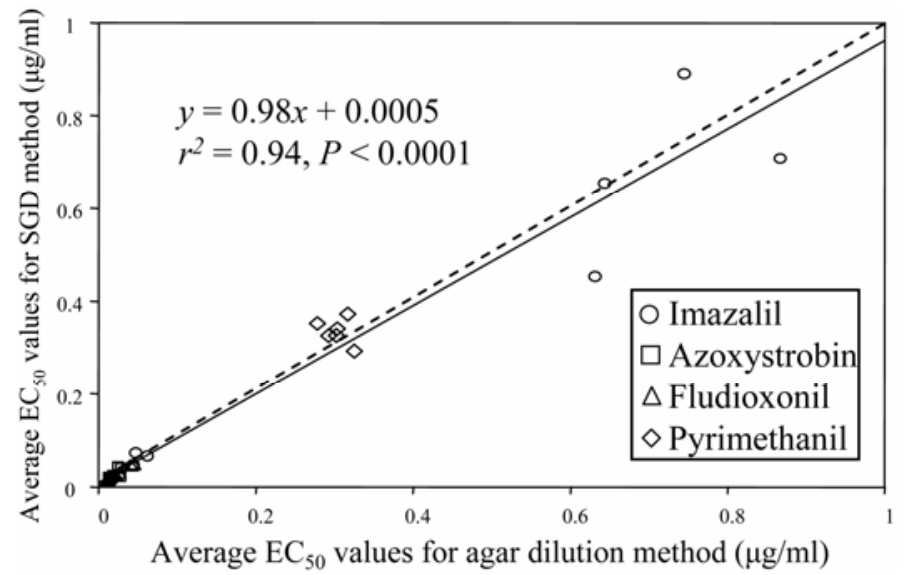

Fig. 1. Regression of effective concentrations to inhibit mycelial growth by $50 \%\left(\mathrm{EC}_{50}\right.$ values) obtained using the spiral gradient dilution (SGD) method on those obtained using the agar dilution method. Data points for inhibition of mycelial growth of seven isolates of Penicillium digitatum are the means of three experiments. The slope and y intercept of the linear regression (solid line) are compared with a 1:1 relationship (dashed line). stone fruit Monilinia fructicola, B. cinerea, and Rhizopus stolonifer to fludioxonil. For pyrimethanil, Sholberg et al. (27) reported a mean $\mathrm{EC}_{50}$ value of $0.314 \mu \mathrm{g} / \mathrm{ml}$ for mycelial growth of a baseline population of 17 isolates of $P$. expansum using a minimal growth medium. This mean $\mathrm{EC}_{50}$ value was very close to those that we determined for $P$. digitatum on PDA and AP media (i.e., 0.31 and $0.21 \mu \mathrm{g} / \mathrm{ml}$, respectively). For $P$. italicum, with a mean $\mathrm{EC}_{50}$ value of
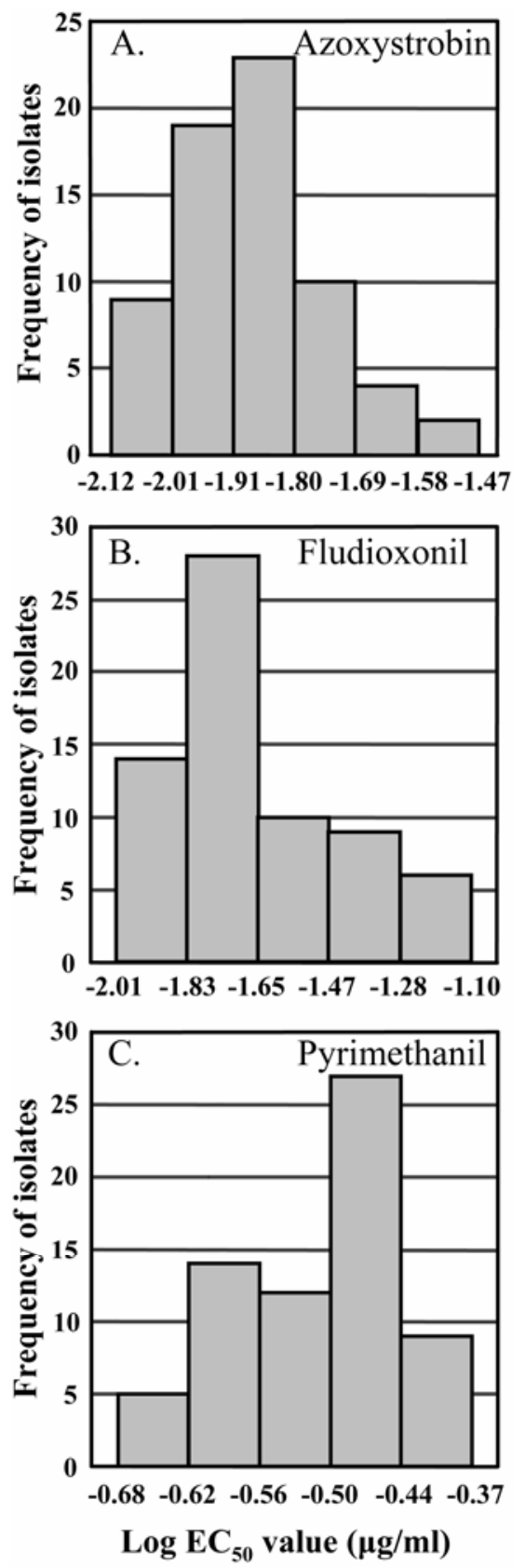

Fig. 2. Frequency histograms of effective concentrations to inhibit mycelial growth of 67 isolates of Penicillium digitatum by $50 \%\left(\mathrm{EC}_{50}\right.$ values) for $\mathbf{A}$, azoxystrobin, $\mathbf{B}$, fludioxonil, and C, pyrimethanil as determined by the spiral gradient dilution method. Bar height indicates the total number of isolates within each bin, and bin width (0.109 for azoxystrobin, 0.182 for fludioxonil, 0.061 for pyrimethanil) was based on Scott's method (26). 
$0.041 \mu \mathrm{g} / \mathrm{ml}$, however, pyrimethanil was found to be more toxic. Although a smaller number of isolates of $P$. italicum than of $P$. digitatum was evaluated in our study, a wider range in sensitivities against pyrimethanil was found for the former species. In comparisons of sensitivities of the fungi for the other two fungicides, the mean $\mathrm{EC}_{50}$ value for azoxystrobin was lower for $P$. digitatum, whereas for fludioxonil it was lower for $P$. italicum. $\mathrm{EC}_{50}$ values for conidial germination of $P$. digitatum in our study ranged from of 0.863 to $1.608 \mu \mathrm{g} / \mathrm{ml}$ on PDA using 21 isolates. Smilanick et al. (28), using a single isolate of $P$. digitatum grown in a potato dextrosebased liquid medium that was adjusted to different $\mathrm{pH}$ values, reported $\mathrm{EC}_{50}$ values between 0.2 and $0.4 \mu \mathrm{g}$ pyrimethanil $/ \mathrm{ml}$ for conidial germination. Fungicide sensitivities for conidial germination were not determined for P. italicum. Future monitoring of sensitivities in these pathogen populations will likely be based on the established fungicide sensitivities against mycelial growth. This is because visual assessment of fungal inhibition is less time-consuming for mycelial growth than for conidial germination, which is determined by microscopic observations.

Agar media were amended with formulated products of the fungicides evaluated, except for thiabendazole, which is used as technical grade for postharvest treatments of citrus fruit. In comparisons of $\mathrm{EC}_{50}$ values for fludioxonil using either the formulated product Scholar 50WP or technical grade material, very similar values were obtained (data not shown). We preferred to use formulated materials in our studies because these are being utilized in fungicide applications in the packinghouse. Although adjuvants in formulated products can potentially modify the activity of the fungicide or its diffusion rate in agar, toxicity values are never absolute because even the agar medium used might interfere with the activity of the fungicide (24).

To obtain a statistically representative sample size for determining population sensitivities, Leung et al. (20) developed the formula: $N=\log (1-P) / \log (1-F)$, where $N$ is the sample size of the population and $P$ is the probability of detecting an outlier at a frequency $F$. In our study, to detect at least one outlier in the population, a sample size of 67 was used for $P$. digitatum. This implies that $95.6 \%$ of all isolates will have $\mathrm{EC}_{50}$ values for mycelial growth within the range that we described with $95 \%$ confidence (20). For conidial germination where we evaluated 21 isolates, $86.7 \%$ of all isolates will fall into the baseline range described with $95 \%$ confidence. Thirty-seven isolates of $P$. italicum were used for the baselines of fludioxonil and pyrimethanil, and 33 isolates were used for azoxystrobin. This implies that 92.2 and $91.3 \%$ of all isolates, respec- tively, will have $\mathrm{EC}_{50}$ values for mycelial growth within the described ranges with 95\% confidence.

The baseline sensitivity of an organism is the range of sensitivities of a sample population before its widespread exposure to a particular chemical (16). Inherent to any population there is variation in the response due to evaluation methods used
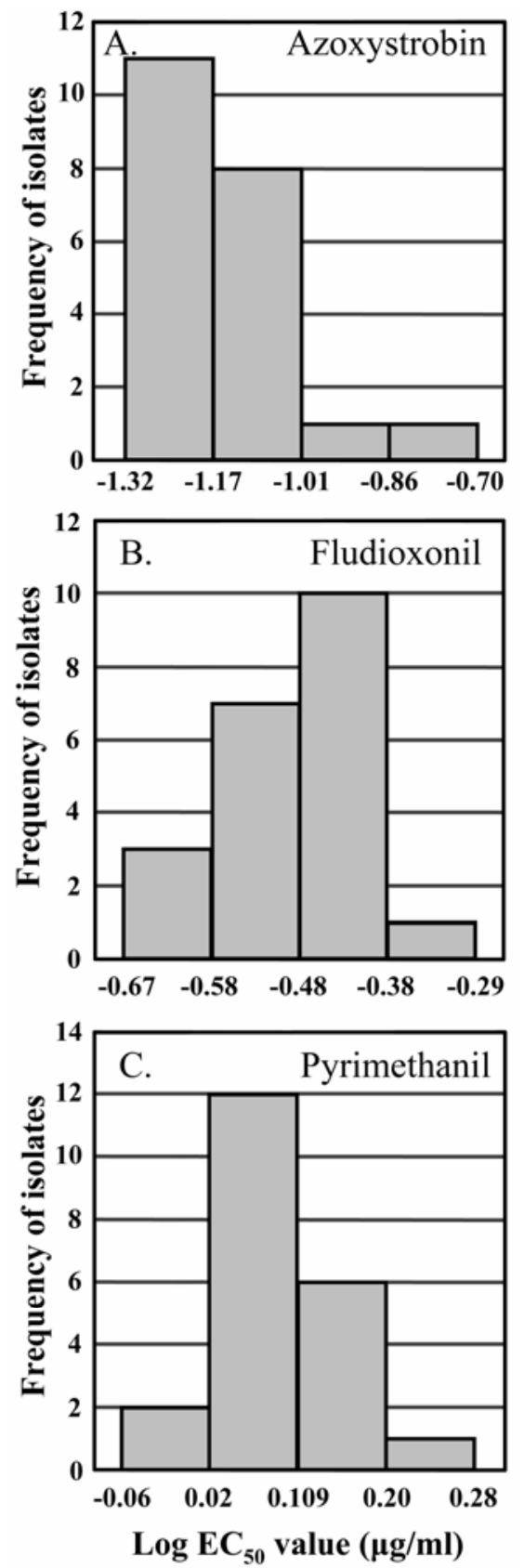

Fig. 3. Frequency histograms of effective concentrations to inhibit mycelial growth of 37 isolates of Penicillium italicum by $50 \%\left(\mathrm{EC}_{50}\right.$ values) for $\mathbf{A}$, azoxystrobin, $\mathbf{B}$, fludioxonil, and $\mathbf{C}$, pyrimethanil as determined by the spiral gradient dilution method. Four isolates that had $\mathrm{EC}_{50}$ values for azoxystrobin $\geq 0.772 \mu \mathrm{g} / \mathrm{ml}$ were not included in the histogram (see Results). Bar height indicates the total number of isolates within each bin, and bin width ( 0.155 for azoxystrobin, 0.096 for fludioxonil, 0.086 for pyrimethanil) was based on Scott's method (26). and, more importantly, due to genetic differences among individuals. In our study, we found that four isolates of $P$. italicum had $\mathrm{EC}_{50}$ values for azoxystrobin at least 25 times greater than the mean value for the remaining 33 isolates evaluated, although this fungus was never exposed to azoxystrobin or the QoI class of fungicides. These four isolates were verified to be $P$. italicum based on morphological and molecular comparisons (data not pre-
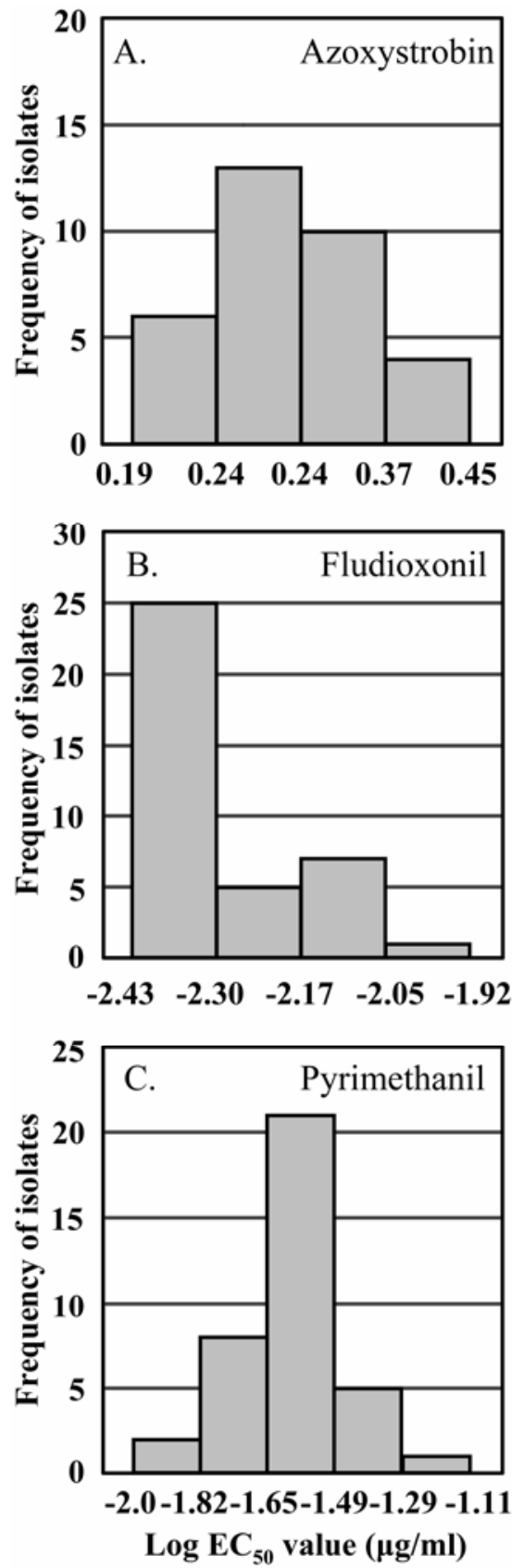

Fig. 4. Frequency histograms of effective concentrations to inhibit conidial germination of 21 isolates of Penicillium digitatum by $50 \%\left(\mathrm{EC}_{50}\right.$ values) for $\mathbf{A}$, azoxystrobin, $\mathbf{B}$, fludioxonil, and C, pyrimethanil as determined by the spiral gradient dilution method. Bar height indicates the total number of isolates within each bin, and bin width $(0.089$ for azoxystrobin, 0.126 for fludioxonil, 0.177 for pyrimethanil) was based on Scott's method (26). 
sented). Thus, these resistant isolates preexisted in field populations of $P$. italicum, resulting in a preliminary estimate of resistance frequency of $10.8 \%$ based on the small number of isolates assessed. Resistant individuals most likely will also preexist for the other fungicides evaluated and in populations of $P$. digitatum, and they may be detected if larger numbers of isolates were evaluated. Therefore, additional studies addressing these frequencies will provide information on the resistance potential for these fungicides. The four isolates of $P$. italicum less sensitive to azoxystrobin represent a distinct subpopulation of the baseline population. In future monitoring for changes in fungicide sensitivities in the populations, gradual or sudden shifts in sensitivity levels will be monitored for fungicides that exhibit quantitative or
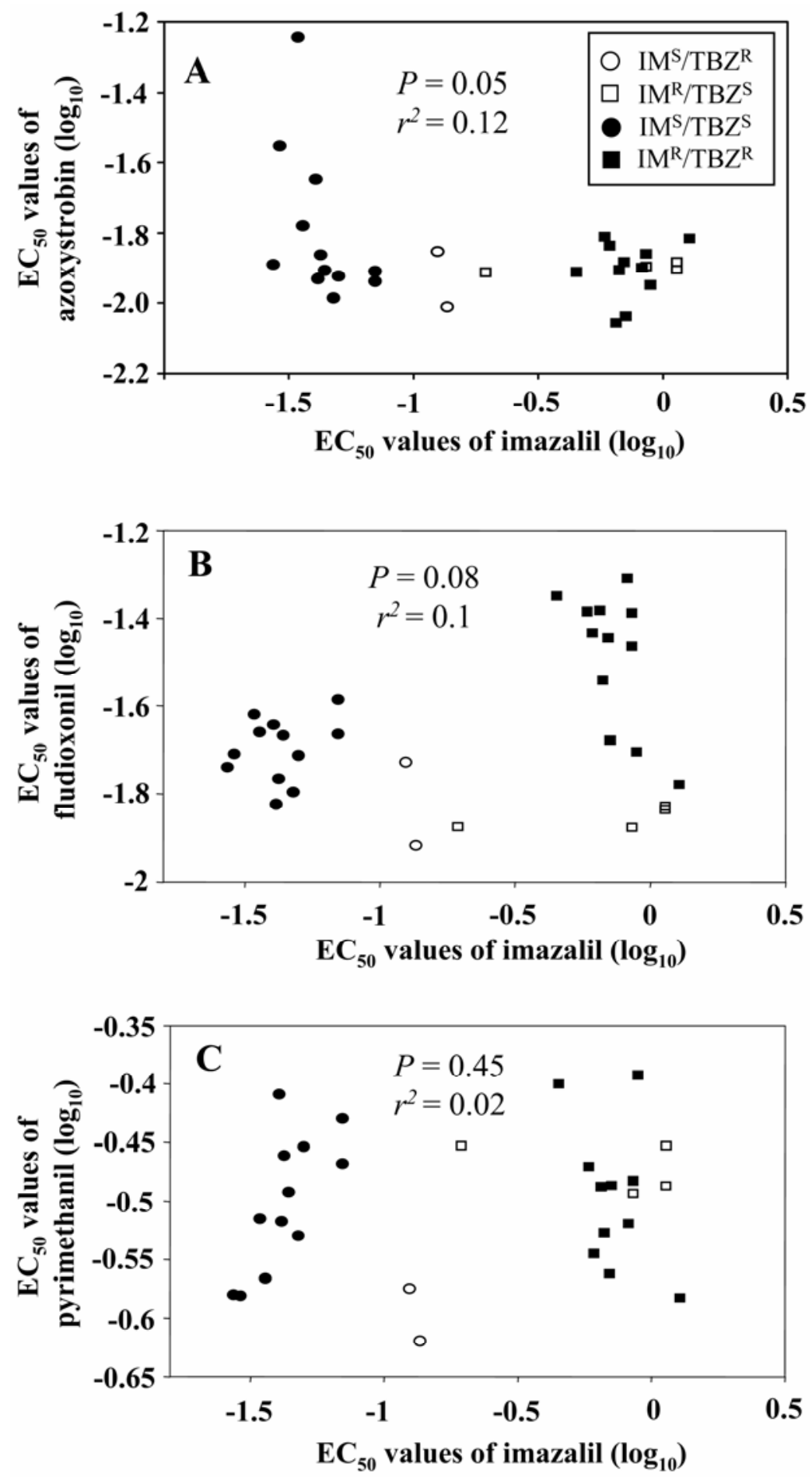

Fig. 5. Scatter plots of effective concentrations to inhibit mycelial growth by $50 \%$ ( $\mathrm{EC}_{50}$ values) for imazalil plotted against those for A, azoxystrobin, B, fludioxonil, and C, pyrimethanil. Different symbols for the 38 isolates of Penicillium digitatum evaluated describe their sensitivity (sensitive or resistant) to imazalil (IM) and thiabendazole (TBZ). The coefficients of determination $\left(r^{2}\right)$ and $P$ values for the linear regressions are indicated.

qualitative resistance, respectively $(16,31)$. Azoxystrobin has been reported to exhibit qualitative as well as quantitative resistance in $V$. inaequalis (17). By presenting the frequency distribution for the sensitive population of $P$. italicum in the histogram with multiple bins and by documenting a resistant subpopulation in our baseline, both types of resistance can be monitored in the future.

$\mathrm{EC}_{50}$ values are the most precise sensitivity measures for fungus-fungicide interactions (3). Although there is no absolutely correct assay for determining in vitro fungicide toxicities, the mycelium-based agar dilution test has been the most commonly used method. Recently, the SGD method was developed as a single-plate assay (11). In our current study with $P$. digitatum and four fungicides, the SGD method was compared with the agar dilution method and was shown to be precise $(\mathrm{CV}=4.9 \%)$ and accurate $(b=1.87 \%)$. Thus, data obtained using the two methods were more similar than in our previous report where the SGD method was developed (11). This is probably because in this latter study nine fungicides and eight fungi were used. In our current study with only one fungus evaluated against three fungicides, less variability was observed as indicated by the high precision. Thus, the SGD method is an excellent alternative to traditional methods for quantification of fungicide toxicities and could have an important role in monitoring changes in fungicide sensitivity in populations of $P$. digitatum (29).

Early in vitro sensitivity studies with anilinopyrimidine fungicides indicated that the culture medium used influenced the inhibitory effect of these fungicides, and reversal of growth inhibition occurred by certain amino acids incorporated into a fully synthetic medium (21). This led to the suggestion that anilinopyrimidines are the first commercial fungicides that interfere with an amino acid biosynthesis pathway, most likely for methionine. As a result, the FRAC-AP committee suggested the use of a synthetic medium free of amino acids in monitoring and resistance risk assessment of Botryotinia fuckeliana to anilinopyrimidine fungicides $(13,19)$. Although in our studies mean $\mathrm{EC}_{50}$ values using the AP medium were significantly lower as compared to PDA, our baseline values were determined using PDA. This was done because of several reasons. The AP medium is laborious to prepare and requires much longer incubation times before fungal growth can be measured (i.e., 5 to 6 days as opposed to 3 days on PDA). Thus, the difference in mean $\mathrm{EC}_{50}$ values of $0.01 \mu \mathrm{g}$ pyrimethanil $/ \mathrm{ml}$ could possibly be due to a stress response of the fungus when grown in a nutrient poor medium. In addition, the natural substrate for $P$. digitatum is the citrus fruit, where amino acids, including methionine, are present. Furthermore, no significant differ- 
ence was observed in percent mycelial growth inhibition at $0.35 \mu \mathrm{g}$ pyrimetha$\mathrm{nil} / \mathrm{ml}$, the concentration where growth of the fungus on PDA was inhibited by $99 \%$ (Table 3).

Because the alternative respiration pathway is known to interfere with the in vitro sensitivity to strobilurin fungicides in a range of fungi $(2,33)$, the inhibitor of this pathway SHAM has been used extensively in in vitro studies with strobilurins $(22,30)$. In our mycelial growth studies with azoxystrobin, $\mathrm{EC}_{50}$ values for $P$. digitatum and $P$. italicum were not significantly different using media with or without the addition of SHAM. Inhibition of growth for P. digitatum was significantly less (i.e., 83.5\%), however, using the nonamended medium at a concentration of $0.25 \mu \mathrm{g}$ azoxystrobin $/ \mathrm{ml}$ as compared to the amended medium, where growth was inhibited by 99\%. Mondal et al. (22) also showed that SHAM did not affect $\mathrm{EC}_{50}$ values for mycelial growth of five citrus pathogens to the strobilurin fungicides azoxystrobin and pyraclostrobin. In our conidial germination studies, however, no inhibition of germination of $P$. digitatum was apparent when azoxystrobin was used alone. Thus, the addition of SHAM was required to determine $\mathrm{EC}_{50}$ values similar to other studies where the effect of strobilurin fungicides on conidial germination was evaluated (30).

Reported sensitivities of baseline isolates of $P$. digitatum to imazalil range from 0.023 to $0.146 \mu \mathrm{g} / \mathrm{ml}$, while for thiabendazole they range from 0.05 to $0.60 \mu \mathrm{g} / \mathrm{ml}$ (5). Based on this information, the discriminatory concentrations we used to characterize an isolate as resistant to imazalil and TBZ were 0.15 and $1 \mu \mathrm{g} / \mathrm{ml}$, respectively. The isolates we used in this study can be assigned to four phenotypes based on their sensitivities to these two fungicides: 12 isolates were sensitive to both imazalil and TBZ, 13 isolates were resistant to both imazalil and TBZ, 11 isolates were resistant to imazalil and sensitive to TBZ, and 2 were sensitive to imazalil and resistant to TBZ. Because of the existence of single- as well as doubleresistant isolates of $P$. digitatum to imazalil and TBZ, cross-sensitivity patterns to the new fungicides were studied for isolates sensitive or resistant to imazalil or TBZ. In our in vitro experiments, no evidence of multiple-resistance was evident. Statistical analyses showed no significant positive correlation between sensitivity to imazalil and the new fungicides. Thus, although the models in the statistical analyses were sometimes significant $(P<0.1)$, the coefficients of determination were very low in each of the regressions $\left(r^{2} \leq 0.12\right)$ (Fig. 5A to C). For $P$. expansum, others have shown that conidial germination and mycelial growth responses in the presence of fludioxonil also did not correlate with sensitivities to TBZ (9). For P. italicum, isolates resistant to TBZ or imazalil were not found, and thus, cross resistance could not be evaluated. Development of baseline sensitivities and monitoring for changes in sensitivity are important antiresistance strategies (3). If shifts in sensitivity occur, rotations and mixtures between different chemical classes can be utilized before resistant populations cause crop losses. Thus, over 25 years after the introduction of imazalil in California packinghouses (14), the registration of azoxystrobin, fludioxonil, and pyrimethanil for postharvest use is of great importance for the citrus industry (1). In this study, baseline sensitivity data for these fungicides on citrus green mold and blue mold pathogens were established using the SGD method, a novel approach for determining 50\% effective concentration values.

\section{ACKNOWLEDGMENTS}

We thank the California Citrus Research Board for financially supporting this research. We also thank the service companies Decco-Cerexagri, FMC, and Pace International, the citrus growers' cooperative Sunkist, as well as Gerald J. Holmes for providing fungal isolates, and Alejandra SotoEstrada for technical assistance and helpful suggestions. This research is part of a Ph.D. dissertation undertaken by L. Kanetis.

\section{LITERATURE CITED}

1. Adaskaveg, J. E., Kanetis, L., Soto-Estrada, A., and Förster, H. 2006. A new era of postharvest decay control in citrus with the simultaneous introduction of three new "reduced-risk" fungicides. Pages 999-1004 in: Proc. Int. Soc. Citric. 10th Int. Citrus Congress - Vol. III. M. ElOtmani and A. Ait-Oubahou, eds. Feb. 15-20, 2004, Agadir, Morocco.

2. Avila-Adame, C., and Köller, W. 2002. Disruption of the alternative oxidase gene in Magnaporthe grisea and its impact on host infection. Mol. Plant-Microbe Interact. 15:493-500.

3. Brent, K. J. 1988. Monitoring for fungicide resistance. Pages 9-11 in: Fungicide Resistance in North America. C. J. Delp, ed. American Phytopathological Society, St. Paul, MN.

4. Brown, G. E., and Eckert, J. W. 2000. Penicillium decays - Blue mold. Page 41 in: Compendium of Citrus Diseases, 2nd ed. L. W. Timmer, S. M. Garnsey, and J. H. Graham, eds. American Phytopathological Society, St. Paul, MN.

5. Bus, V. G. 1992. ED $\mathrm{ED}_{50}$ levels of Penicillium digitatum and $P$. italicum with reduced sensitivity to thiabendazole, benomyl, and imazalil. Postharv. Biol. Technol. 1:305-315.

6. Eckert, J. W., and Eaks, I. L. 1989. Postharvest disorders and diseases of citrus fruit. Pages 179-260 in: The Citrus Industry, Vol. V - Crop Protection, Postharvest Technology, and Early History of Citrus Research in California. W. Reuther, E. C. Calavan, and G. E. Carman, eds. University of California, Division of Agricultural and Natural Resources, Oakland, CA. Publ. no. 3326.

7. Eckert, J. W., Sievert, J. R., and Ratnayake, M. 1994. Reduction of imazalil effectiveness against citrus green mold in California packinghouses by resistant biotypes of Penicillium digitatum. Plant Dis. 78:971-974.

8. Eckert, J. W., and Wild, B. L. 1983. Problems of fungicide resistance in Penicillium rot of citrus fruit. Pages 525-526 in: Pest Resistance to Pesticides. G. P. Georghiou and T. Saito, eds. Plenum Publishing, New York.

9. Errampalli, D. 2003. Effect of fludioxonil on germination and growth of Penicillium expan- sum and decay in apple cvs. Empire and Gala. Crop Prot. 23:822-827.

10. Förster, H., Driever, G. F., Thompson, D. C., and Adaskaveg, J. E. 2007. Postharvest decay management for stone fruit crops in California using the 'reduced-risk' fungicides fludioxonil and fenhexamid. Plant Dis. 91:209-215.

11. Förster, H., Kanetis, L., and Adaskaveg, J. E. 2004. Spiral gradient dilution, a rapid method for determining growth responses and 50\% effective concentration values in fungusfungicide interactions. Phytopathology 94:163170 .

12. Gehmann, K., Nyfeler, R., Leadbeater, A. J., Nevill, D., and Sozzi, D. 1990. CGA 173506: A new phenylpyrrole fungicide for broadspectrum disease control. Proc. Brighton Crop Prot. Conf.-Pests Dis. 2:399-406.

13. Hilber, U. W., and Schüepp, H. 1996. A reliable method for testing the sensitivity of Botryotinia fuckeliana to anilinopyrimidines in $\mathrm{vi}$ tro. Pestic. Sci. 47:241-247.

14. Holmes, G. J., and Eckert, J. W. 1999. Sensitivity of Penicillium digitatum and $P$. italicum to postharvest citrus fungicides in California Phytopathology 89:716-721.

15. Kanetis, L., Soto-Estrada, A., and Adaskaveg, J. E. 2004. Baseline sensitivities of Penicillium digitatum populations to azoxystrobin, fludioxonil, and pyrimethanil. (Abstr.) Phytopathology 94:S49.

16. Kendall, S. J., and Hollomon, D. W. 1998. Fungicide resistance. Pages 87-108 in: Fungicidal Activity-Chemical and Biological Approaches to Plant Protection. D. Hutson and J. Miyamoto, eds. John Wiley \& Sons, West Sussex, England.

17. Köller, W., Parker, D. M., Turechek, W. W., and Avila-Adame, C. 2004. A two-phase resistance response of Venturia inaequalis populations to the QoI fungicides kresoxim-methyl and trifloxystrobin. Plant Dis. 88:537-544.

18. Köller, W., Wilcox, W. F., and Parker, D. M. 2005. Sensitivity of Venturia inaequalis populations to anilinopyrimidine fungicides and their contribution to scab management in New York. Plant Dis. 89:357-365.

19. Leroux, P., and Gredt, M. 1996. In vitro methods for monitoring pyrimethanil resistance of Botrytis cinerea in grapevine. EPPO Bull 26:186-188.

20. Leung, H., Nelson, R. J., and Leach, J. E. 1993. Population structure of plant pathogenic fungi and bacteria. Adv. Plant Pathol. 10:157205.

21. Masner, P., Muster, P., and Schmid, J. 1994 Possible methionine biosynthesis inhibition by pyrimidinamine fungicides. Pestic. Sci. 42:163-166.

22. Mondal, S. N., Bhatia, A., Shilts, T., and Timmer, L. W. 2005. Baseline sensitivities of fungal pathogens of fruit and foliage of citrus to azoxystrobin, pyraclostrobin, and fenbuconazole. Plant Dis. 89:1186-1194.

23. Okada, A., Banno, S., Ichiishi, A., Kimura, M., Yamaguchi, I., and Fujimura, M. 2005. Pyrrolnitrin interferes with osmotic signal transduction in Neurospora crassa. J. Pestic. Sci. 30:378-383.

24. Osorio, J. M., Adaskaveg, J. E., and Ogawa, J. M. 1994. Inhibition of mycelial growth of Monilinia species and suppression and control of brown rot blossom blight of almond with iprodione and E-0858. Plant Dis. 78:712-716.

25. Rosslenbroich, H. J., and Stuebler, D. 2000. Botrytis cinerea - History of chemical control and novel fungicides for its management. Crop Prot. 19:557-561.

26. Scott, D. W. 1979. On optimal and data-based histograms. Biometrika 66:605-610.

27. Sholberg, P. L., Bedford, K., and Stokes, S. 2005. Sensitivity of Penicillium spp. and $\mathrm{Bo}$ trytis cinerea to pyrimethanil and its control of blue and gray mold of stored apples. Crop 
Prot. 24:127-134.

28. Smilanick, J. L., Mansour, M. F., Mlikota Gabler, F., and Goodwine, W. R. 2006. The effectiveness of pyrimethanil to inhibit germination of Penicillium digitatum and to control citrus green mold after harvest. Postharv. Biol. Technol. 42:75-85.

29. Soto-Estrada, A., Kanetis, L., Förster, H., and Adaskaveg, J. E. 2004. A new air-sampling method for monitoring fungicide sensitivity and visualizing known types of resistance in Penicil- lium digitatum populations in citrus packinghouses. (Abstr.) Phytopathology 94:S97.

30. Steinfeld, U., Sierotzki, H., Parisi, S., Poirey, S., and Gisi, U. 2001. Sensitivity of mitochondrial respiration to different inhibitors in Venturia inaequalis. Pest Manag. Sci. 57:787-796.

31. Wolfe, M. S. 1982. Dynamics of the pathogen population in relation to fungicide resistance. Pages 139-148 in: Fungicide Resistance in Crop Protection. J. Dekker and S. G. Georgopoulos, eds. Center for Agricultural Publish- ing and Documentation, Wageningen, The Netherlands.

32. Wong, F. P., and Corza, J. 2004. Control of summer patch and anthracnose on an annual bluegrass green in southern California. Fungic. Nematicide Tests 60:T058.

33. Wood, P. M., and Hollomon, D. W. 2002 Review - A critical evaluation of the role of alternative oxidase in performance of strobilurin and related fungicides acting at the $\mathrm{Q}_{0}$ site of complex III. Pest. Manag. Sci. 59:499-511. 